\title{
THE EFFECT OF WORK CULTURE ON VISITOR SATISFACTION AT PDIKM (MINANGKABAU CULTURAL DOCUMENTATION AND INFORMATION CENTER)
}

\author{
* M. Rodi Mansyuri ${ }^{1}$ and Afriva Khaidir ${ }^{2}$ \\ ${ }^{1}$ Magister of Public Administration, Universitas Negeri Padang, Padang, Indonesia \\ ${ }^{2}$ Faculty Social and Science, Universitas Negeri padang, Padang, Indonesia \\ 1m.rodi.mansyuri@gmail.com ${ }_{2}^{2}$ af.khaidir@gmail.com
}

*Corresponding Author, Received: Augustus 14, 2019, Revised: October 17, 2019, Accepted: November 11, 2019

\begin{abstract}
The purpose of this study was to examine the effect of work culture on visitor satisfaction at PDIKM Padang Panjang City. This study uses a quantitative approach. The study population was tourists visiting PDIKM Padang Panjang City. The sample in this study consisted of 376 respondents who were determined using the Slovin formula with an error rate of $5 \%$ and the sampling technique was done through accidental sampling. Data analysis techniques using simple regression analysis. The findings show that there is a significant influence between work culture on visitor satisfaction by $13.8 \%$. The results of the study concluded that work culture influences visitor satisfaction at PDIKM Padang Panjang City.
\end{abstract}

Keywords: Work Culture, Visitor Satisfaction

\section{INTRODUCTION}

Tourism is an interesting thing to observe, especially in terms of management and development. Tourism is an integral part of national and regional development which is carried out in a systematic, planned, integrated, sustainable, and responsible manner while still providing protection for religious and cultural values. Tourism development is needed to encourage equality of business opportunities and benefits and be able to face the challenges of changing local, national and global life. The role of tourism is also very large for Indonesia through the amount of foreign exchange received by the existence of such tourism, this makes it a reliable economic power to support the wheels of 


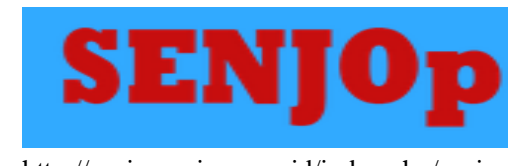

http://senjop.ppj.unp.ac.id/index.php/senjop
Science and Environmental Journals for Postgraduate

Vol. 2 No. 1 (pp. 56-62) December 2019

p_ISSN 2655-5085

e_ISSN 2655-5239

government at the center and in the regions. Tourism is very potential because tourism resources will not run out even if continuously explored, it will even be better if the object is explored and developed to the maximum.

Law Number 10 of 2009 Concerning Tourism emphasizes that the implementation of Tourism is aimed at increasing national income in order to improve the welfare and prosperity of the people, expand and equalize business and employment opportunities, encourage regional development, introduce and utilize tourism objects and attractions in Indonesia and foster a sense of love for the motherland and strengthen friendship between nations. Tourism has a large impact on the socio-economic conditions of local communities, including the impact on community income, the impact on employment opportunities and the impact on prices and the impact on community benefits. Therefore the availability of tourist objects and attractions is a big capital in the development of tourism which is supported by the availability of various supporting facilities and infrastructure, the existence of security and order guarantees as well as government efforts to support and facilitate tourism activities.

The only institution that is most competent in the tourism sector is the Tourism Office. The role of the Department of Tourism as a government agency in developing tourism includes the maintenance and management of facilities and infrastructure. One of the dominant factors in increasing regional development and automatically influential in the success of national development. The policy of the regional government, especially the Tourism Office in developing tourism in general, is to provide infrastructure in various forms of facilities, activities of corruption between the government apparatus and the private sector and promotion arrangements at home and abroad. More serious changes made by the government, such as better management of tourism objects and professionalism, procurement of various supporting facilities and infrastructure facilities as well as supporting tourism as well as the development and exploration of existing tourism potential.

The potential of natural tourism in the city of Padang Panjang include Minang Fantasy (MIFAN), Lubuk Mata Cat Baths, Flowering Hill, Seven-Level Waterfall and Batu Batu Batirai Cave. In addition to nature tourism, there are also other tours that are 


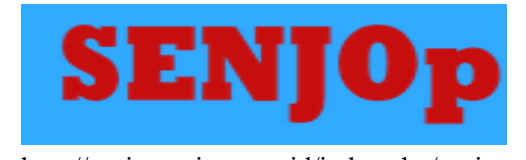

http://senjop.ppj.unp.ac.id/index.php/senjop
Science and Environmental Journals for Postgraduate

Vol. 2 No. 1 (pp. 56-62) December 2019

p_ISSN 2655-5085

e_ISSN 2655-5239

made a priority in the development of tourism, including historical and cultural tourism, while historical and cultural tourism include the Minangkabau Cultural Information and Documentation Center (PDIKM), Azazi Mosque, Diniyyah Putri, Thawalib College, Institute Seni Indonesia (ISI), Featured High School and Kauman Muhammadiyah.

Giese and Cote in Fandi and Gregory (2007: 195) mentioned that there are three main components in the definition of customer satisfaction, namely: (1) customer satisfaction is a response (emotional or cognitive); (2) the response concerns a particular focus (expectations, products, consumption experience, and so on); (3) the response occurs at a certain time (after consumption, after product / service selection, based on accumulative experience, etc.). Satisfaction as a perception of a product or service that has fulfilled its expectations (Handi Irawan, 2008: 3). So satisfaction means someone's perception or assessment of the product or service it receives. In measuring visitor satisfaction, there are four methods of measuring visitor satisfaction that are classified by Kotler in Fandy and Gregory (2011: 314), namely the Complaints and Suggestions System, Shadow Customers, Analysis of Consumer Losses, and Customer Satisfaction Surveys. In addition, visitor satisfaction indicators according to Aldri and Afriva (2017) consisting of happy, happy, facilities found in accordance with expectations, availability of sophisticated and modern information, performance of services provided, and consumer expectations.

Then according to Budi Paramita (in Taliziduhu, 2005: 208) work culture is a group of basic thoughts or mental programs that can be used to improve work efficiency and human cooperation owned by a group. Work culture in the opinion of Rastogi (in Aldri Frinaldi, 2014: 182) is a work culture values that is able to lead them to work quality and productively. Tourism of Padang Panjang City still has many shortcomings, based on the results of an interview with one of the visitors on October 20, 2019 at PDIKM that the facilities and infrastructure in the tourist area are still inadequate, where we can see there are still no breastfeeding places for mothers, still the absence of a special place to charge mobile phones, laptops and others, and toilets that are still not in accordance with existing regulations. 


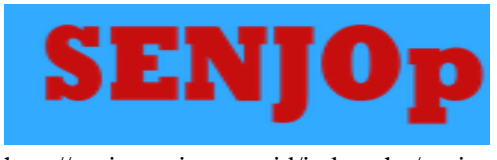

http://senjop.ppj.unp.ac.id/index.php/senjop

Based on the brief description above, the authors are interested in conducting research and analyzing more deeply about the study with the title "The Influence of Work Culture of Visitor Satisfaction at PDIKM (Center for Documentation and Information of Minangkabau Culture) Padang Panjang City" as for the formulation of the problem in this study is to find out whether there is the influence of Work Culture on Visitor Satisfaction at PDIKM Padang Panjang City.

\section{METHOD}

The method in this study uses quantitative research. The approach used in research, processes, hypotheses, down field, data analysis and data conclusions up to writing using aspects of measurement, calculation, formula, and certainty of numerical data. The population in this study were tourists visiting the Padang Panjang PDIKM. The sample in this study consisted of 376 respondents who were determined using the Slovin formula and the sampling technique was done by accidental sampling technique. The data analysis technique used is simple linear regression. Besides that, to get a general picture of the two variables, frequency, mean, and TCR (Respondents' Achievement Rate) are also used.

\section{RESULTS AND DISCUSSION}

If the Work Culture (X2) variable regression is performed on the visitor satisfaction variable $(\mathrm{Y})$ then the results can be seen in the following table:

Table 1. Contribution Results (R) Work Culture Variables on Visitor Satisfaction

Model Summary ${ }^{b}$

\begin{tabular}{|c|c|c|c|c|c|}
\hline Model & $\mathrm{R}$ & R Square & $\begin{array}{l}\text { Adjusted R } \\
\text { Square }\end{array}$ & $\begin{array}{l}\text { Std. Error of } \\
\text { the Estimate }\end{array}$ & $\begin{array}{l}\text { Durbin- } \\
\text { Watson }\end{array}$ \\
\hline 1 & $.375^{\mathrm{a}}$ & .140 & .138 & 3.593 & 1.769 \\
\hline \multicolumn{6}{|c|}{ a. Predictors: (Constant), Budaya Kerja } \\
\hline \multicolumn{6}{|c|}{ b. Dependent Variable: Kepuasan Pengunjung } \\
\hline \multicolumn{6}{|c|}{ Source: Research Results 2020} \\
\hline
\end{tabular}




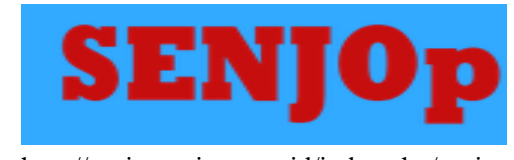

http://senjop.ppj.unp.ac.id/index.php/senjop
Science and Environmental Journals for Postgraduate

Vol. 2 No. 1 (pp. 56-62) December 2019

p_ISSN 2655-5085

e_ISSN 2655-5239

Based on the above tebel can be understood that, Adjusted R Square value of 0.138 , which means the influence of work culture on visitor satisfaction by $13.8 \%$. The remaining $86.2 \%$ is influenced by other variables not examined in this study. Furthermore, to strengthen the interpretation that the influence of work culture on visitor satisfaction is significant, it can be seen from the following ANOVA $(\mathrm{F})$ table:

\section{Table 2. Anova Test Results (F) Work Culture Variables} on Visitor Satisfaction

ANOVA $^{b}$

\begin{tabular}{|c|c|c|c|c|c|c|}
\hline \multicolumn{2}{|c|}{ Model } & \multirow{2}{*}{$\begin{array}{l}\begin{array}{l}\text { Sum of } \\
\text { Squares }\end{array} \\
788.184\end{array}$} & \multirow[t]{2}{*}{$\mathrm{df}$} & Mean Square & \multirow{2}{*}{$\frac{F}{61.049}$} & \multirow{2}{*}{$\frac{\text { Sig. }}{.000^{\mathrm{a}}}$} \\
\hline 1 & Regression & & & 788.184 & & \\
\hline & Residual & 4828.625 & 374 & 12.911 & & \\
\hline & Total & 5616.809 & 375 & & & \\
\hline
\end{tabular}

a. Predictors: (Constant), Budaya Kerja

b. Dependent Variable: Kepuasan Pengunjung

Source: Research Results 2020

Based on the table above, the significance value of 0.000 , because the significance of the test value is smaller than 0.05 , it can be concluded that the work culture variables affect visitor satisfaction. Then to test the significance of the constant (c), the $T$ test is carried out. From the $t$ test that has been done it can be seen in the following table:

Tabel 3. Hasil Uji T

Variabel Budaya Kerja terhadap Kepuasan Pengunjung

Coefficients $^{\text {a }}$

\begin{tabular}{|c|c|c|c|c|c|c|c|c|}
\hline \multirow[b]{2}{*}{ Model } & & \multicolumn{2}{|c|}{$\begin{array}{c}\text { Unstandardized } \\
\text { Coefficients }\end{array}$} & \multirow{2}{*}{$\begin{array}{c}\text { Standardized } \\
\text { Coefficients } \\
\text { Beta } \\
\end{array}$} & \multirow[b]{2}{*}{$\mathrm{t}$} & \multirow[b]{2}{*}{ Sig. } & \multicolumn{2}{|c|}{$\begin{array}{c}\text { Collinearity } \\
\text { Statistics }\end{array}$} \\
\hline & & B & Std. Error & & & & Tolerance & VIF \\
\hline \multirow[t]{2}{*}{1} & (Constant) & 28.848 & 2.441 & & 11.820 & .000 & & \\
\hline & $\begin{array}{l}\text { Budaya } \\
\text { Kerja }\end{array}$ & .819 & .105 & .375 & 7.813 & .000 & 1.000 & 1.000 \\
\hline
\end{tabular}

a. Dependent Variable: Kepuasan

Pengunjung

Source: Research Results 2020 


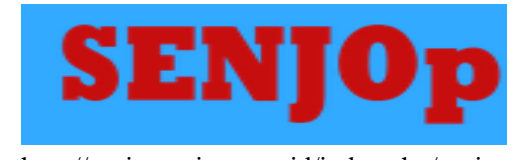

http://senjop.ppj.unp.ac.id/index.php/senjop
Science and Environmental Journals for Postgraduate

Vol. 2 No. 1 (pp. 56-62) December 2019

p_ISSN 2655-5085

e_ISSN 2655-5239

Based on the table above, the significance value of 0,000 is less than 0.05 so it can be concluded that Ho is rejected and Ha is accepted, which means there is a variable influence of work culture on visitor satisfaction in PDIKM Padang Panjang City. Based on the results of the second hypothesis, it was found that work culture variables partially had a positive and significant effect on visitor satisfaction. This is evidenced from the results of data processing using the help of SPSS 16 software, that found the significance value of the strategy variables on visitor satisfaction amounted to $0,000<0.05$.

The magnitude of influence possessed by the work culture variable on this visitor satisfaction variable is partially at $13.8 \%$. This $13.8 \%$ value is obtained based on the adjusted $\mathrm{r}$ square value after the $\mathrm{T}$ test of the first hypothesis is carried out with a significance of 0,000 . The foregoing means in line with the opinion of Gunadi (2015) that work culture is beneficial to change attitudes and behavior to increase customer satisfaction. Attitude is interpreted as a tendency to respond to something consistently to support or by paying attention to a particular object. Attitudes related to behavior directed at a particular object, person, or situation. Work culture is a way of working everyday based on values so that it can provide satisfaction for the community.

Work culture serves to build confidence in human resources or instill certain values that influence attitudes and behavior in accordance with customer expectations. This expectation will lead to customer satisfaction and dissatisfaction. Work culture will affect customer satisfaction as service users. Work culture has the power to realize customer satisfaction. The application of values, beliefs and assumptions has a strong influence on employees who can ultimately meet customer expectations in the form of customer satisfaction. The influence of work culture will meet customer expectations in the form of customer satisfaction.

In addition, the influence of work culture on visitor satisfaction also reinforces the theory of Dezonda R. Pattipawae (2011: 35) explains that work culture is a philosophy based on the view of life as values that become the nature, habits and driving forces, entrenched in the life of a group society or organization, then reflected from attitudes into behavior, beliefs, ideals, opinions and actions that manifest as "work" or "work so as to create satisfaction to customers" 


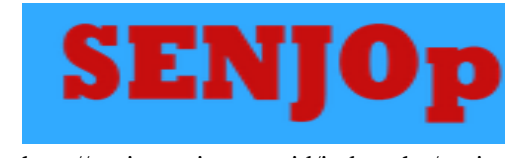

http://senjop.ppj.unp.ac.id/index.php/senjop

\section{CONCLUSION}

Based on the results of the research and discussion described above, it can be concluded that there is a positive and significant influence of work culture on the visitor satisfaction variable with an adjusted $\mathrm{r}$ square value of 0.138 or $13.8 \%$ while the remaining $86.2 \%$ was not examined in this study.

\section{REFERENCES}

Arikunto, Suharsimi. 2010. Prosedur Penelitian Suatu Pendekatan Praktik. Jakarta: Rineka Cipta.

Badan Meteorologi Klimatologi dan Geofisika. 2014. Gempa Bumi. (http://www.bmkg.go.id/bmkg_pusat/Geofisika/gempabumi.bmkg)

Rovicky. 2013. Patahan Sumatera (Patahan Semangko).

(http://rovicky.wordpress.com/2013/07/02/patahan-sumatera-patahansemangko/),

Sugiyono. 2013. Metode Penelitian Kuantitatif Kualitatif dan R \& D. Bandung: Alfabeta Iswandi dan Indang. 2017. Pendekatan Sistem, : Rajawali Printing 